\title{
Adequacies and inadequacies in the anthropometric and dietetic profiles of preschool children
}

\author{
Maria do Socorro Silva Alencar ${ }^{1}$, Susy Érika de Lima Barros ${ }^{1}$, lanamara Seabra Borges ${ }^{2}$, \\ Kamilla Nogueira Cavalcante ${ }^{1}$, Martha Teresa Siqueira Marques Melo ${ }^{1}$, Ivone Freires de Oliveira Costa Nunes ${ }^{1}$, \\ Apolônia Maria Tavares Nogueira ${ }^{1}$, Clélia de Moura Fé Campos ${ }^{1}$
}

DOI: http://dx.doi.org/10.7322/jhgd.119290

\begin{abstract}
Introduction: Nutritional conditions and food patterns in preschool children are elements that emphasise the importance of health monitoring in this period of nutritional transition, both to ensure nutritional adequacy and how much to intervene in identified inadequacies. Hence, it may also constitute a strategy for public programs and school health services to make decisions.
\end{abstract}

Objective: To analyse the anthropometric and dietary profiles of pre-schoolers of a pole city in Northeastern Brazil.

Methods: This is a cross-sectional evaluative study with 114 children aged $2-5$ years, of both genders, in three municipal centres of early childhood education. Anthropometry was used to measure weight and height, and the nutritional condition was assessed using the indexes Height for Age $(\mathrm{H} / \mathrm{A})$, Weight for Age (W/A), Weight for Height (W/H) and Body Mass Index for Age (BMI/A) in z-score values with classifications established by the World Health Organization. The food intake record was done by direct weighing of the food menu offered during a week in the three institutions. This procedure allowed for the evaluation of the nutritional composition of menus, from the estimates in percentages, average and standard deviations of total calories, macronutrients (proteins, carbohydrates and lipids) and micronutrients (calcium, iron, vitamins $\mathrm{A}$ and $\mathrm{C}$ ), to the adjustments and comparisons to the reference values of the Recommended Dietary Allowances, National Research Council and the PNAE recommendations, by age stages, in full-time units, $1-3$ years, $700 \mathrm{kcal} ; 4-5$ years, $950 \mathrm{kcal}(70 \%$ coverage prediction of daily nutritional requirements) and the part-time units, these same ranges of age, respectively, 200 and 270 $\mathrm{kcal}(20 \%$ coverage for forecasting nutritional needs daily), considering adequate consumption to that with a variation of up to $10 \%$ above or below $100 \%$ of these recommendations.

Results: Most of the preschool children had adequate nutritional conditions, especially those of full-time units, with relative frequencies (W/A: $94.5 \%$; W/H: 89.5\%, BMI/A: $81.7 \%$ ). There were registered also overweight percentages higher than the deficits, in the indices W/A (22.2\%), P/E (33.3\%) to municipal early childhood centre CMEI-A girls; the indices W/A, W/H, BMI/A (23.8\% each) in CMEI B-boys. In relation to the adequacy of the food profile, there was only convergence between the offer and the recommendation of $70 \%$ coverage of the daily energy needs, for pre-schoolers of 4-5 years from the centre of full-time units (mean: $951.2 \pm 172.3 \mathrm{kcal}$ ). As for nutrients, inadequacies had a trend in the coverage of the daily needs on the menu offered in part-time units.

Conclusion: Although most children do not present indicative of nutritional risk, requires attention to food portion that was with inadequacies of nutritional condition, with emphasis on weight surplus, while the readjustments in per capita and in portions of the menu implemented in those locations.

Key words: preschool, nutritional condition, anthropometry, school feeding, nutrition policy.

1 Universidade Federal do Piauí, Centro de Ciências da Saúde, Departamento de Nutrição, SG 13, Campus Ministro Petrônio Portella, $\mathrm{S} / \mathrm{N}^{\circ}$. ININGA, Teresina - Piauí, Brazil.

2 Secretaria Estadual de Educação e Cultura (SEDUC), Governo do Estado do Piauí, Brasil.

Corresponding author: Maria do Socorro Silva Alencar. Rua Prof. Elias Torres 1365, Edifício Tropcs Ap. 401 - São Cristóvão. CEP 64052-160 - Teresina - Piauí - Brazil.

Suggested citation: Alencar MSS, Barros SEL, Borges IS, Cavalcante KN, Melo MTSM, Nunes IFOC, et al. Adequacies and inadequacies in the anthropometric and dietetic profiles of preschool children. J Hum Growth Dev. 26(2): 234-242. Doi: http://dx.doi.org/10.7322/ jhgd.119290. 


\section{INTRODUCTION}

The nutritional condition, when it is reviewed using anthropometric indicators, predicts health conditions and adequate or inadequate nutrition of one age group, being an instrument widely used in basic actions in health services and in school to curb nutritional disorders such as excesses or deficits in the children's population as well as the risk of chronic disease in adult life ${ }^{1}$.

In Brazil, the findings of the two latest surveys conducted with children under five years of age, (National Survey on Demography and Health-PNDS/1996; National Survey of Demography and Health of the Child and the Woman-PNDS/2006), point to a decrease in prevalence of deficits of Height for Age (H/A) of $13.5 \%$ to $6.8 \%$ and Weight for Height (W/H) of $2.1 \%$ to $1.6 \%$, thus confirming a reduction of around $50 \%$ in the prevalence of malnutrition in this population ${ }^{2,3}$.

Despite this reduction, the percentage of children with growth retardation by linear indicator (H/A) still reflects concerns among researchers of children's health, because, at the same time, in the epidemiological context of nutritional transition in the last decades, findings of the family budget survey (POF 2008-2009) ${ }^{4}$ pointed to a $33.5 \%$ prevalence of overweight among children ages five to nine years. The paradoxical situation in these studies demonstrated that the prevalence of overweight has surpassed that of malnutrition, namely, a replacement of deficits by excess weight, confirming the reduction of the prevalence of malnutrition in this age group and other segments of the population ${ }^{1,4}$.

It is important to emphasize the importance of adequate food supply to the nutritional needs of children from two to five years by public institutions, in particular the municipal early childhood centres (CMEIs), favoured by the National School Feeding Program (PNAE), whose guidelines provide the assistance partially or fully for this food, which should provide energy and nutrients needed to guarantee growth and development potential and curb nutritional deficiencies and disorders, aiming at biopsychosocial progress ${ }^{5}$. However, their inadequacy is a respectable predictor for low and overweight prevalence in this generation.

Thus, the objective of this study is to analyse the anthropometric and dietary profiles of pre-schoolers in a pole city of the Brazilian Northeast territory.

\section{METHODS}

This is a cross-sectional analytical study of three public CMEIs from South pole city in the Northeast, Brazil, involving children ages $2-5$ years, regularly enrolled in such school units. The study was determined in two steps. First, we chose the area that was supposed to carry a greater number of CMEIs (47 units), which was attended by 23.086 preschool children, for a random drawing of the three units in a nominal listing provided by the Municipal Department of Education and Culture. Second, it was estimated by equiprobability, with $5 \%$ alpha error and a power of test of 95\%, 377 sampled of all students enrolled in the selected units. In this sample, $30 \%$ were selected, corresponding to 114 children chosen equally from each of the three units. Thirty-eight children were sampled from each of the total enrolled CMEI, through random drawings in the classes offered. The centres received the following designations: CMEI, CMEI-B (part-time service) and CMEI-C (full-time).

For the nutritional evaluation, researchers collected information on date of birth, gender, weight and height. To obtain the weight and height, the recommendations of the Ministry of Health (2008) ${ }^{6}$ were adopted, in which each measure was taken three times, made the sum of three values for the arithmetic average, registering it in the data collection instrument.

The weight was taken using an electronic portable platform scale, Bioland brand EF934, with a capacity to weigh up to $200 \mathrm{~kg}$ and a sensitivity of $100 \mathrm{~g}$. Each child was placed in the centre of the equipment, wearing a school uniform, barefoot, upright, with feet together and arms stretched along the body. After keeping the child standing in this position and the value of the weight being fixed on the display, the value was taken ${ }^{6}$.

Height was measured using a measuring tape with a capacity of $1.5 \mathrm{~m}$ and a sensitivity of $1.0 \mathrm{~mm}$, fixed on a wall at a height of $150 \mathrm{~cm}$ from the floor. This measure was carried out with each child standing barefoot with the head free of props, in upright position, arms extended along the body, head up, staring at a fixed point in the height of the eyes, legs and feet together, in addition to heels, calves, buttocks, shoulder blades and back of head (occipital region), leaning on the wall ${ }^{6}$. When the child was unable to touch the five points, it was tried to touch at least three of them.

This review process was supplemented by the following: conversion of homemade measures on paper; application of cooking factors and correction when needed; calculation of the percentage of contribution of each food [formula: food amount x 100/total (sum of weights of all food preparation)]; application of the percentage of contribution to the average portion weighing of preparations obtained in [formula: (average value portion) $\mathrm{x}$ (percentage of contribution)/100] ${ }^{8}$; quantification of energy and nutrients by the Brazilian Table of Food Composition (TACO) $)^{9}$ and nutritional information labels of processed products.

In possession of these data, the percentage of adequacy of energy, macro and micro-nutrients of the menus analysed from the values of the Recommended Dietary Allowances (RDAs), National Research Council (NRC), and the recommendations of the PNAE, according to age stages in full-time units, for children of 1-3 years, 700 kcal; of 4-5 years, $950 \mathrm{kcal}$ (forecast $70 \%$ coverage of the daily nutritional requirements), and the part-time units, for children in those age ranges, respectively, 200 and 270 kcal (forecast of $20 \%$ coverage of the daily nutritional requirements), considering how appropriate that consumption with a variation of up to $10 \%$ above or below $100 \%$ of these recommendations ${ }^{5}$.

The analysis of the database generated in the tab of a Microsoft Excel spreadsheet (2010) was held at the software Statistical Package for the Social Scienc- 
es - SPSS 18.0. The anthropometric indexes by gender and age group were described in mean values, standard deviation and relative frequencies (\%). The Fischer exact test, with a statistical significance level ( $p<0.05)$, was used to decide on similarities or differences between the percentages of global nutritional assessments. Dietary variables included: energy (kcal), macronutrients (carbohydrates, proteins, lipids) and micronutrients (vitamins A and C, iron, calcium) of the menus offered, with adequacies and inadequacies displayed in relative frequencies (\%), averages and standard deviations, and the analysis was made by comparison with average values of nutrients and percentages of coverage recommended by the PNAE ${ }^{5}$.

The project was approved by the Research Ethics Committee of the Federal University of Piauí, with the number 667,516, 5/29/2014.

\section{RESULTS}

Of the 114 children evaluated, 33 (28.9\%) belonged to the age group of $2-3$ years and 81 (71.1\%) belonged to the group of $4-5$ years, with an average age $1.04 \pm 4.07$ years. It was observed, in the distribution by gender, discreet male prevalence (51.8\%) over feminine (48.2). As for anthropometric indicators, there was record of height suitable for the age in all children surveyed.

Most of the children presented adequate nutritional conditions, with female prevalence from CMEI-C by indexes W/A; W/H. On the other hand, in CMEI-A, all the boys were eutrophic by index W/H compared to $55.6 \%$ of the girls. CMEI-B, the children obtained the same percentages of eutrophy for W/H ratios; BMI/A (71.4\%; 70.6\%), respectively, for boys and girls (Table 1 ).

Table 1: \% Distribution of anthropometric indicators of 114 preschool children by gender in surveyed CMEls. Teresina, Piauí, 2015

\begin{tabular}{|c|c|c|c|c|c|c|c|}
\hline \multirow[b]{2}{*}{$\begin{array}{l}\text { Anthropometric } \\
\text { Indicators }\end{array}$} & \multirow[b]{2}{*}{$\begin{array}{l}\text { Nutritional } \\
\text { condition }\end{array}$} & \multicolumn{2}{|c|}{ CMEI-A $^{1}$} & \multicolumn{2}{|c|}{ CMEI-B $^{1}$} & \multicolumn{2}{|c|}{ CMEI-C ${ }^{2}$} \\
\hline & & $\begin{array}{c}n=20 \\
F\end{array}$ & $\begin{array}{c}n=18 \\
M\end{array}$ & $\begin{array}{c}n=21 \\
F\end{array}$ & $\begin{array}{c}n=17 \\
M\end{array}$ & $\begin{array}{c}n=18 \\
F\end{array}$ & $\begin{array}{c}n=20 \\
M\end{array}$ \\
\hline \multirow{3}{*}{ W/A (\%) } & Deficit & - & - & 4.8 & 5,9 & 5,5 & - \\
\hline & Eutrofic & 90,0 & 77.8 & 71,4 & 94,1 & 89,0 & 1 \\
\hline & Exess & 10,0 & 82,2 & 23,8 & - & 5,5 & - \\
\hline \multirow[t]{3}{*}{ W/H (\%) } & Deficit & - & 11.1 & 4.8 & 17.6 & 5.5 & 5.0 \\
\hline & Eutrofic & 100.0 & 55.6 & 71.4 & 70.6 & 89.0 & 90.0 \\
\hline & Excess & - & 33,3 & 23,8 & 11,8 & 5,5 & 5,0 \\
\hline \multirow[t]{3}{*}{ BMI/A (\%) } & Deficit & 10.0 & 11.1 & 4.8 & 17.6 & 5.5 & 5.0 \\
\hline & Eutrophic & 80.0 & 77.8 & 71.4 & 70.6 & 83.4 & 80.0 \\
\hline & Excess & 10.0 & 11.1 & 23.8 & 11.8 & 11.1 & 15.0 \\
\hline
\end{tabular}

Total $=114[\mathrm{M}=$ male (59); $\mathrm{F}=$ female (55)]. Fischer exact test: $\mathrm{p}>0.05$.

$\mathrm{CMEI}$ - Centro Municipal de Educação Infantil.

1 Part-time unit, 2 Full-time unit.

In most indexes, the percentage of overweight identified overcame the deficit weight, regardless of gender or CMEI searched, especially girls from CMEI-A, in which $33.3 \%$ were overweight versus $11.1 \%$ of low weight, according to the W/H index. In CMEI-C, boys and girls showed reduced excess weight, except in the index BMI/A (11.1\%; 15.0\%), respectively (Table 1).
What is consolidated on the nutritional condition of preschool children is highlighted in Figure 1, in which it is noted that there were no statistically significant differences between the age groups and genders ( $\mathrm{p}>0.05)$.

Regarding the dietary profile, in the full-time centre, there was a similarity between the offerings and the recom-

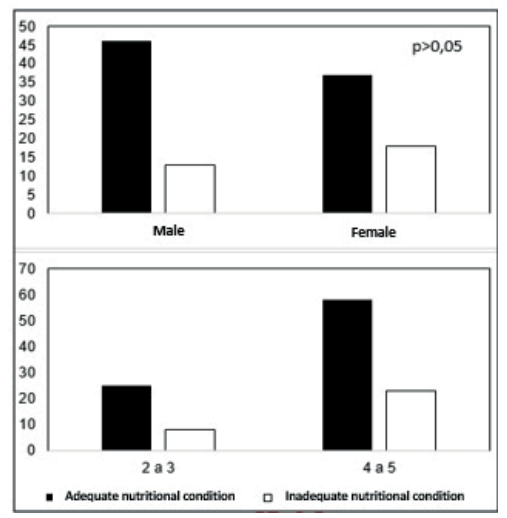

Figure 1: Global nutritional condition of 114 preschool children according to z-score by WHO criteria, by gender and age group. Teresina, Piauí, 2015. 
mendation of $70 \%$ of the daily nutritional requirements for children of $4-5$ years, averaging (951.2 $\pm 172.3 \mathrm{Kcal}$ ), but offering surplus energy to children 1-3 years (Table 2 ).

In the part-time units, there was insufficient caloric coverage at both age stages (CMEI-B); however, in CMEI-A it was observed a percentage of coverage next to recommended for the larger and higher for preschool minors (18.7\%; 25.3\%), simultaneously (Figure 2)

As for the average values of adequacy of menus in energy and nutrients in CMEI-A, high values were identified in energy, carbohydrates, proteins, vitamins A and C and iron, and below values were identified only in lipids and calcium. In CMEI-B, high means were found in pro- tein and vitamin C; low means in energy, carbohydrates, vitamin A, lipids and calcium; and appropriate and inappropriate in iron (1-3; 4-5 years), respectively. The menu already running in CMEI-C presented high values of energy and macronutrients and vitamin $\mathrm{C}$, and low percentages of micronutrients: iron and vitamin $\mathrm{A}$ for children of 1-3 years (Table 3 ).

\section{DISCUSSION}

The majority of preschoolers, with discreet predominance of male children, similar to the data of the PNDS 2006³, presented appropriate anthropometric pro-

Table 2: Average values of recommendations by age group and average energy and nutrients from the food offered in part-time and full-time CMEls. Teresina, Piauí 2015.

\begin{tabular}{|c|c|c|c|c|c|c|c|}
\hline \multirow[t]{2}{*}{$\begin{array}{l}\text { Energyl } \\
\text { Nutrients }\end{array}$} & \multicolumn{2}{|c|}{$\begin{array}{c}\text { Recomendations } \\
1 \\
20 \%\end{array}$} & \multicolumn{2}{|c|}{$\begin{array}{c}\text { Recomendations } \\
1\end{array}$} & \multirow[t]{2}{*}{ CMEI- $\mathrm{A}^{2}$} & \multirow{2}{*}{$\begin{array}{c}\text { CMEI-B }^{2} \\
\text { Median ( } \pm \text { ) }\end{array}$} & \multirow[t]{2}{*}{ CMEI-C 3} \\
\hline & $1-3$ & $4-5$ & $1-3$ & $4-5$ & & & \\
\hline Energy (Kcal) & 200 & 270 & 700 & 950 & $\begin{array}{c}252.7 \pm \\
91.0\end{array}$ & $\begin{array}{c}156.3 \pm \\
74.8\end{array}$ & $\begin{array}{c}951.2 \pm \\
172.3\end{array}$ \\
\hline $\begin{array}{l}\text { Carbohydrates } \\
\text { (g) }\end{array}$ & 32.5 & 43.9 & 114.9 & 154.4 & $\begin{array}{c}44.0 \pm \\
11.9\end{array}$ & $\begin{array}{c}22.7 \pm \\
12.4\end{array}$ & $\begin{array}{c}147.1 \pm \\
41.9\end{array}$ \\
\hline $\begin{array}{l}\text { Proteins } \\
\text { (g) }\end{array}$ & 6.3 & 8.4 & 21.9 & 29.7 & $\begin{array}{l}11.9 \pm \\
9.2\end{array}$ & $9.1 \pm 6.8$ & $27.7 \pm 4.7$ \\
\hline Lipids (g) & 5.0 & 6.8 & 17.5 & 23.8 & $\begin{array}{c}3.39 \pm \\
2.8\end{array}$ & $2.7 \pm 1.8$ & $23.9 \pm 5.1$ \\
\hline Vit. A $(\mu \mathrm{g})$ & 60.0 & 80.0 & 210.0 & 280.0 & $\begin{array}{c}275.7 \pm \\
379.8\end{array}$ & $\begin{array}{c}38.6 \pm \\
64.8\end{array}$ & $\begin{array}{c}153.0 \pm \\
113.5\end{array}$ \\
\hline Vit. C (mg) & 3.0 & 5.0 & 12.0 & 19.0 & $\begin{array}{c}34.7 \pm \\
40.4\end{array}$ & $\begin{array}{c}11.0 \pm \\
21.2\end{array}$ & $\begin{array}{c}40.34 \pm \\
7.0\end{array}$ \\
\hline Calcium (mg) & 100.0 & 160.0 & 350.0 & 560.0 & $\begin{array}{c}62.3 \pm \\
49.1\end{array}$ & $\begin{array}{c}34.8 \pm \\
23.8\end{array}$ & $\begin{array}{c}371.1 \pm \\
142.1\end{array}$ \\
\hline Iron (mg) & 1.4 & 2.0 & 4.9 & 7.0 & $2.7 \pm 1.0$ & $1.5 \pm 0.7$ & $3.7 \pm 0.6$ \\
\hline
\end{tabular}

1 Recommended Dietary Allowances - RDAs, the National Research Council - NRC. (Adopted document by the resolution FNDE $n^{\circ}$. 32/2006).

2 Part-time unit (has to attend to $20 \%$ of daily nutritional necessities of preschoolers).

3 Full-time unit (has to attend to $70 \%$ of daily nutritional necessities of preschoolers).

$\mathrm{CMEI}$ - Centro Municipal de Educação Infantil

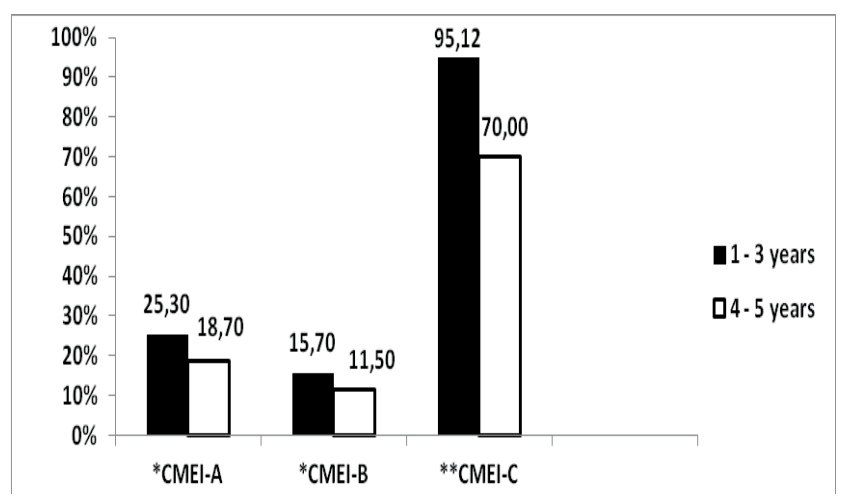

CMEI - Centro Municipal de Educação Infantil

* Part-time unit (has to attend to $20 \%$ of daily nutritional necessities of preschoolers).

** Full-time unit (has to attend to $70 \%$ of daily nutritional necessities of preschoolers).

Figure 2: Average values of coverage of the energy value by age group in part-time and full-time CMEls. Teresina, Piauí, 2015. 
Table 3: Energy adequacy median and feed nutrients offered to age groups of $1-3 ; 4-5$ years. Teresina, Piauí, 2015.

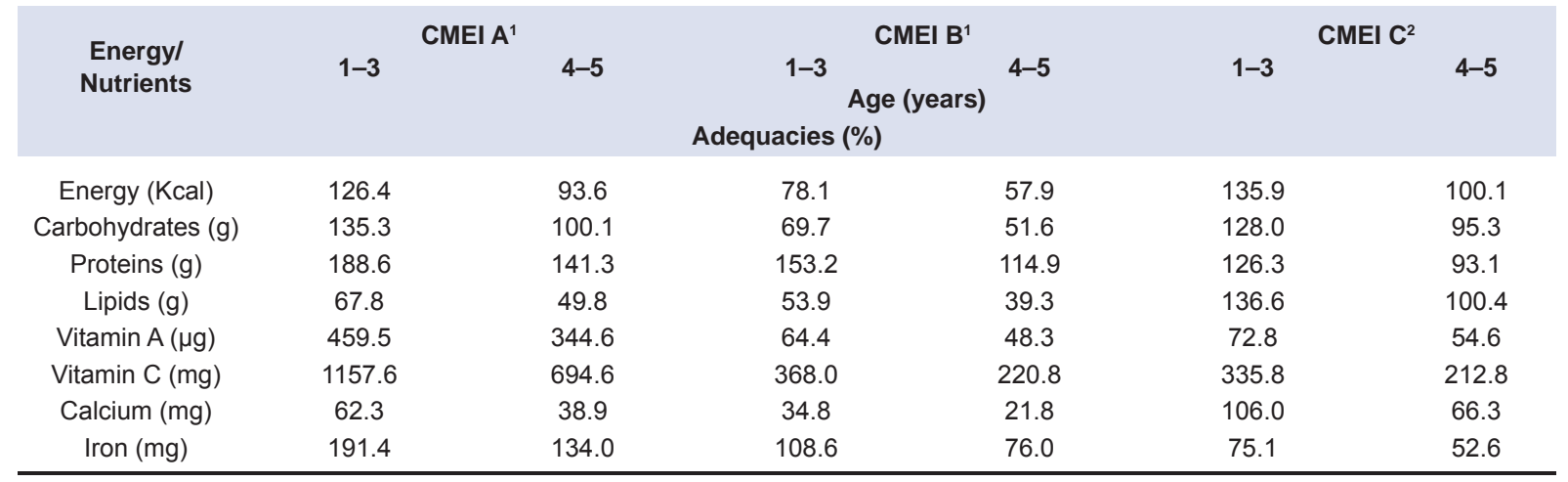

CMEI - Centro Municipal de Educação Infantil.

1 Part-time unit; 2 Full-ti.

files according to the indexes W/A, W/H, BMI/A, including the index H/A, which showed a linear growth suitable for all surveyed.

These results can be considered relevant because they reflect the living conditions of this group attending the CMEIs, since these children are at an age stage marked by sharp physical development and gradual growth of height and weight, and the first three years are vital to their future quality of life ${ }^{10}$. Also, these results demonstrate that good outcomes can be achieved from the implementation of nutritional and health policies for mother and child groupings.

Despite this, the share of overweight children was higher than the share with low birth weight, which can predispose this population to diseases by excess food consumption to replace those of insufficient consumption of macro and micronutrients, a tendency in societies in nutritional transition, which has been reiterated in epidemiological studies.

Sperandio et al. ${ }^{11}$, assessing 350 children from 2-to-5-years-old in public and private schools, in the municipality of Viçosa, Minas Gerais, Brazil, from different growth curves (WHO, 2006) ${ }^{7}$, identified a higher incidence of overweight [W/H (27.9\%); W/A (27.3\%) among the boys and BMI/AA (26.4\%) among girls] than insufficient weight. Such results are higher than those of the present study, except in relation to the finding of overweight (33.3\%), according to the W/H of girls from CMEI-A.

Findings from other national authors, although different when compared to those found in this research, also reiterate the overweight condition among pre-schoolers of both genders, in public institutions: Martino et al. ${ }^{12}$, analysing the nutritional condition and food consumption of 186 preschoolers at the Educational Centre of Alfenas, Minas Gerais, Brazil, detected the following anthropometric profile: $58.3 \%, 68.2 \%$ and $43.7 \%$ of eutrophic children by indexes W/A, W/H and H/A, respectively.

The risk for being overweight prevailed in 13.3\% to $\mathrm{W} / \mathrm{A}$ and $21.9 \%$ to $\mathrm{W} / \mathrm{H}$. The prevalence of overweight among children were $1.9 \%(\mathrm{~W} / \mathrm{A})$ and $4 \%(\mathrm{~W} / \mathrm{H})$. Nascimento et al. ${ }^{13}$, using the same indexes, identified $15.6 \%$ at risk of obesity, $4.7 \%$ overweight and $4.9 \%$ with severe obesity; Santos et al. ${ }^{14}$ observed in the BMI/A risk of over- weight in $29.2 \%$ and $19 \%$ obesity, in $8.3 \%$ and $9.5 \%$ of the male population and female population, respectively; Saldiva et al. ${ }^{15}$, employing the $\mathrm{W} / \mathrm{H}$ index, observed $14.0 \%$ of boys and girls with excess weight.

This profile, as the excess weight has the support of researchers and institutions for health surveillance, which in recent years have recorded substantial proportions of overweight in both preschool age children ${ }^{11-15}$ and children in school and adolescent phases ${ }^{1}$, as the 2008/09-POF, in all income groups from all regions of Brazil, there was an excess of weight and obesity frequency in this population ${ }^{4}$.

The WHO suggests that this fact is due to the excess energy that is preferably stored in the form of fat and protein, as in males. In addition, the boys tend to be more active than girls, and the evaluations carried out through cutaneous folds measures revealed that girls tend to have more fat reserves than boys; also, the pubescent stage is conducive to weight gain, which can extend to adolescence $^{16}$.

This evidence adds a new concern in the context of public policy, with the nutritional condition of children, childhood obesity is a social matter with worldwide repercussions and with different determinant factors: early weaning; increased consumption of foods high in fats, sugars and salt; sedentary lifestyle (allied to changes in modes of transport and use of technological devices); as well as advertising and an industrialised food supply ${ }^{17}$.

Thus, the assessment of nutritional conditions of preschoolers is timely, since preschool is the phase in which proper nutrition enhances the speed of growth and development and promotes the construction of healthy eating habits; therefore, it requires implementation of intervention measures related to food and physical activity ${ }^{16}$.

It should be noted that the occurrence of children with a profile of eutrophy in CMEI-C (Table 1) is relatively larger than the children in the other two centres, which may be related to the fact that the children in this centre receive full-time attention and are offered four meals per day (mid-morning snack, lunch, afternoon snack and dinner), sufficient to meet their everyday demands for energy and nutrients.

As for the dietary profile, the oscillations observed in percentages of adequacy and coverage of energy and 
nutrients of the menus offered in these centres may be related to lack of standardisation in per capita, in weight and measurement equivalence and in portioning of food, i.e. the distributed portions are equal for all children without distinction by age stage, contrary to the recommendations of the PNAE that predict for the part-time and full-time, respectively, $1-3$ years $=200 / 700 \mathrm{kcal} /$ day and $4-5$ years $=270 / 950 \mathrm{kcal} / \mathrm{day}^{5}$.

Maybe the deficit in the energy value of the meals distributed to children of part-time CMEIs results from an underestimation of the quantity of food served for breakfast and lunch-dinner, even if unintentionally. It can be a strategy adopted by the developer of the food service because consider very short time interval between the offering of the first meal and the arrival of the child unit, because in general it was used as the power supply about to two hours after.

Nascimento et al. ${ }^{18}$, on analysing the children of Taubaté, São Paulo, Brazil, in that same age group phase, observed that the amount of servings offered at the main meal (lunch) was overrated, when it is compared to the recommended amount, as well as it did not exist in the nurseries surveyed, standardisation to the offer of menus, i.e. there was discretionary, both preparations portioning in per capita, as in actual amount consumed by each child. This result is similar to those found in the current study in one of the units of part-time and full-time, for the range of $1-3$ years.

In this way, the studies reaffirm that the menus offered for that segment of the population require portioning and per capita differentiation by age groups in order to better meet their nutritional needs, whereas consumption beyond or below the values estimated for RDAs at this age can contribute negatively to the performance of linear growth and development during adolescence ${ }^{18-21}$.

These data suggest that the range of $100 \%$ coverage of energy and nutrient recommendations during the time spent in day care is relatively difficult, especially when the centre offers only one meal, the situation in CMEIs A and $\mathrm{B}$. Therefore, the food at home before and after the child goes to the centre should serve as a complement, in order to reach the child's nutritional needs. Nutrition and support guidelines require educators in day care centres and parents at home ${ }^{22}$.

The occurrence of a low supply of lipids to preschoolers of CMEIs A and B exhibited similarity with the findings of the survey of Silva and Gregory ${ }^{21}$, in which the percentage was below the recommended amount, a fact that demonstrates the need for the adoption of an adequate technical dietary formula to increase the energy density of the food served, whereas this nutrient, greater energy contributor, in situations of inadequacies, can feature low power consumption for this age group ${ }^{21,22}$.

Regarding vitamin $\mathrm{A}$, the high percentage identified on the menu from CMEI-for all ages stands out. This fact is a reflection of the daily supply of food sources on the menu (papaya and watermelon, offered twice a week; milk, bell peppers, carrots, squash and sweet potatoes, weekly). On the other hand, CMEI-B and CMEI-C have not met the recommendations proposed for this vitamin in any of the age groups. Another study, in the same munici- pality, with the institutionalised population in a partial regime, to diagnose prevalence of deficiency of this vitamin, observed inadequate supply, although children receiving $29 \%$ of diet fitness in relation to their daily nutritional requirements of vitamin $\mathrm{A}^{23}$.

The high values of vitamin $\mathrm{C}$ in the menus evaluated may be related to the fact that on the day of weighing foods, the menus included fruit juices and fruits, sources of this nutrient. This is similar to the results found by Bernardi et al. ${ }^{19}$ when assessing the dietary intake of children between two and six years of age, there was a high consumption of food sources of vitamin C, which was due to the offering of fruits as dessert after the main meals.

The inadequate intake of calcium found in this study can be attributed to the fact that, in the week food registry, the offer of this nutrient was insufficient, because, in these institutions, certainly, it is possible to meet this demand for school meals, with a supply of food sources, such as dark green leafy vegetables, dairy products and canned sardines, whose costs do not justify its absence on the menu ${ }^{5,16,24}$. Tavares et al. ${ }^{24}$ caution that four-year-old children (more often in this study), by having access to a variety of other foods, can consume less milk than the younger ones.

The analysis of dietary iron, too, showed irregularities in the contribution of this micronutrient, which draws attention, therefore, it is known that his disability constitutes nutritional problem that impacts children's growth and cognitive and psychosocial development ${ }^{19.25}$.

Despite the positive results for the linear growth of the population-based study, which highlights changes in the pattern of the Brazilian child's height when comparing the data from research studies of previous decades, there is a need for greater attention to those children who were at risk for nutritional by excess or deficit ${ }^{19}$.

The inadequacies in the percentages of caloric cover, macro and micronutrients checked in menus implemented in these centres could possibly be non-compliant with recommendations arising from proposed nutritional $\mathrm{PNAE}^{5}$, either due to a lack of proper portioning ${ }^{18}$ by incompatibility between the menus planned at the management level and implemented by the CMEIs.

Furthermore, this inadequacy of the dietary profile, particularly in the part-time units, can be a reflection of the limitations implicit in the registration method of directly weighing food, since there is no method capable of estimating these contributions without misunderstandings ${ }^{8}$; on the other hand, this inadequacy can also be connected with obstacles in the food services of these CMEIs, such as the physical and functional structure, financial resources for the provision of nutritional program menus, and human and material resources.

It is expected from this study, the implementation of a program of continuous and permanent health education under the responsibility of the managers, educators and employees of these units, giving emphasis to actions of nutritional surveillance, to extend this process of evaluation with other research from other body measurements (perimeters, circumferences and skinfold thickness), as well as the association between food consumption and anthropometric profile; train- 
ings with employees about proper and safe food and nutrition; standardisation of techniques for preparation, production and distribution of these meals and local nutrition management planning in accordance to the rules of the program.
In short, the aim is a nutritional intervention in preschoolers diagnosed with harms to health and prevention of excess or deficit in the children adequately nourished, seeking thus a full monitoring of the health and nutrition of the children surveyed.

\section{REFERENCES}

1. Ramires EKNM, Meneses RCE, Oliveira JS, Oliveira MAA, Temoteo TL, Longo-Silva G, et al. Estado nutricional de crianças e adolescentes de um município do semiárido do Nordeste brasileiro. Rev Paul Pediatr. 2014;32(3):200-207. DOI: http://dx.doi.org/10.1590/0103-05822014323

2. Brasil. Ministério da Saúde. Pesquisa nacional sobre demografia e saúde da criança e da mulher: PNDS 1996. [cited 2014 May 30]Available from: <http://bvsms.saude.gov.br/bvs/publicacoes/relatorio_pnds_2006. pdf>.

3. Brasil. Ministério da Saúde. Pesquisa nacional de demografia e saúde da criança e da mulher: PNDS 2006: dimensões do processo reprodutivo e da saúde da criança. [cited 2014 May 30] Available from: <http:// bvsms.saude.gov.br/bvs/publicacoes/relatorio_pnds_2006.pdf>.

4. Instituto Brasileiro de Geografia e Estatística. Pesquisa de Orçamento Familiar 2008-2009. Aquisição alimentar e domiciliar per capta Brasil e grandes regiões. Rio de Janeiro: IBGE; 2010. [cited 2014 May 30] Available from: <http://www.ibge.gov.br>.

5. Brasil. Ministério da Educação. Conselho Deliberativo do Fundo Nacional de Desenvolvimento da Educação. Resolução FNDE/CD n.38, de 16 de julho de 2009. Dispõe sobre o atendimento da alimentação escolar aos alunos da educação básica no Programa Nacional de Alimentação Escolar (PNAE). Diário Oficial República Federativa do Brasil. [cited 2014 May 30] Available from: <http://www.fnde.gov.br/index. php/ae-legislacao>.

6. Brasil. Ministério da Saúde. Secretaria de Atenção à Saúde. Departamento de Atenção Básica. Protocolos do sistema de vigilância alimentar e nutricional-SISVAN na assistência à saúde. Brasília: Ministério da Saúde; 2008; p.61.

7. World Health Organization. The WHO child growth standards, 2006. [cited 2012 June 13] Available from: $<$ http://www.who.int/childgrowth>.

8. Barbosa L, Chaves OC, Santos AA, Vigato TC, Correa MLM. Como medir a ingestão alimentar? Rev Eletr Interdisciplinar. 2012;1(8):33-9.

9. Núcleo de Estudos e Pesquisas em Alimentação (NEPA). Tabela brasileira de composição de alimentos: TACO, versão 2. Campinas: UNICAMP; 2006; p.105.

10.Brasil. Ministério da Saúde. Conselho Nacional de Saúde. Resolução n.466/12. Dispõe sobre princípios em pesquisa envolvendo seres humanos. [cited 2014 May 30] Available from: http://conselho.saude.gov. br/resolucoes/2012/Reso466.pdf.

11. Sperandio N, Sant'Ana LFR, Francheschini SCC, Priore SE. Comparação do estado nutricional infantil com utilização de diferentes curvas de crescimento. Rev Nutr. 2011;24(4):565-74. DOI: http://dx.doi. org/10.1590/S1415-52732011000400005

12. Martino HSD, Ferreira AC, Pereira CNA, Silva RR. Avaliação antropométrica e análise dietética de pré-escolares em centros educacionais municipais no sul de Minas Gerais. Ciênc Saúde Coletiva. 2010;15(2):5518. DOI: http://dx.doi.org/10.1590/S1413-81232010000200031

13. Nascimento APB, Ferreira ML, Molina SMG. Avaliação antropométrica de pré-escolares em Piracicaba, SP: da desnutrição para a obesidade. ConScientia Saúde. 2010;9(4):707-13.

14.Santos GG, Sousa JB, Silva JKM, Bitencourt VR. Análise do cardápio e avaliação antropométrica de crianças atendidas por uma creche municipal. Ensaios Ciências: Ciênc Biol Agrárias Saúde. 2011;15(6):31-46.

15.Saldiva SRDM, Silva LFF, Saldiva PHN. Avaliação antropométrica e consumo alimentar em crianças menores de cinco anos residentes em um município da região do semiárido nordestino com cobertura parcial do programa bolsa família Rev Nutr. 2010;23(2):221-9. DOI: http://dx.doi.org/10.1590/S141552732010000200005

16. Lourenço M, Santos C, Carmem I. Estado nutricional e hábitos alimentares em crianças de idade pré-escolar. Rev Enferm Referência. 2014;4(1):7-14.

17. Caldeira KMS, Souza JMP, Souza SB. Excesso de peso e sua relação com a duração do aleitamento materno em pré-escolares. J Hum Growth Dev. 2015; 25(1):89-96. DOI: http://dx.doi.org/10.7322/jhgd.96786

18. Nascimento VG, Salvador EP, Silva JPC, Bertoli CJ, Blake MT, Leone C. Excesso de peso em pré-escolares: análise de uma intervenção possível. J Hum Growth Dev. 2012; 22(1): 11-16. DOI: http://dx.doi. org/10.7322/jhgd.20044 
19.Bernardi JR, Cezaro C, Fisberg RM, Fisberg M, Rodrigues GP, Vitolo MR. Consumo alimentar de micronutrientes entre pré-escolares no domicílio e em escolas de educação infantil do município de Caxias do Sul (RS). Rev Nutr. 2011;24(2):253-61. DOI: http://dx.doi.org/10.1590/S1415-52732011000200006

20.Barbosa RMS, Soares EA, Lanzilloti HS. Avaliação da ingestão de nutrientes de crianças de uma creche filantrópica: aplicação do consumo dietético de referência. Rev Bras Saúde Matern Infant. 2007;7(2):15966. DOI: http://dx.doi.org/10.1590/S1519-38292007000200006

21.Silva MMDC, Gregório EL. Avaliação da composição nutricional dos cardápios da alimentação escolar das escolas da rede municipal de Taquaraçu de Minas - MG. HU Rev. 2012;37(3):387-94.

22.Longo-Silva G, Toloni MHA, Goulart RMM, Taddei JA. Avaliação do consumo alimentar em creches públicas em São Paulo, Brasil. Rev Paul Pediatr. 2012; 30(1):35-41. DOI: http://dx.doi.org/10.1590/S010305822012000100006

23.Paiva AA, Rondó PHC, Gonçalves-Carvalho CMR, Illison VK, Pereira JA, Vaz-de-Lima LRA, et al. Prevalência de deficiência de vitamina A e fatores associados em pré-escolares de Teresina, Piauí, Brasil. Cad Saúde Pública. 2006; 22(9): 1979-87. DOI: http://dx.doi.org/10.1590/S0102-311X2006000900029

24. Tavares BM, Veiga GV, Yuyama LKO, Bueno MB, Fisberg MR, Fisberg M. Estado nutricional e consumo de energia e nutrientes de pré-escolares que frequentam creches no município de Manaus, Amazonas: existem diferenças entre creches públicas e privadas? Rev Paul Pediatr. 2012;30(1):42-50. DOI: http://dx.doi. org/10.1590/S0103-05822012000100007

25. Machado EHS, Leone C, Szarfarc SC. Deficiência de ferro e desenvolvimento cognitivo. Rev Bras Crescimento Desenvolvimento Hum. 2011;21(2):368-73. DOI: http://dx.doi.org/10.7322/jhgd.20025

This article is distributed under the terms of the Creative Commons Attribution 4.0 International License (http://creativecommons.org/licenses/by/4.0/), which permits unrestricted use, distribution, and reproduction in any medium, provided you give appropriate credit to the original author(s) and the source, provide a link to the Creative Commons license, and indicate if changes were made. The Creative Commons Public Domain Dedication waiver (http://creativecommons.org/publicdomain/zero/1.0/) applies to the data made available in this article, unless otherwise stated. 


\section{Resumo}

Introdução: O estado nutricional e o padrão alimentar de crianças na fase pré-escolar são elementos que ressaltam a importância da vigilância à saúde, nesse cenário de transição nutricional, tanto para garantir as adequações, quanto para intervir nas inadequações identificadas, podendo, inclusive, se constituir em estratégia para a tomada de decisões dos agentes públicos escola e serviço de saúde.

Objetivo: Analisar os perfis antropométrico e dietético de pré-escolares em cidade polo do Nordeste brasileiro.

Método: Trata-se de estudo avaliativo transversal, com 114 crianças entre 2 a 5 anos, de ambos os sexos, em três centros municipais de educação infantil. Foi utilizada a antropometria para aferir peso e estatura, sendo o estado nutricional avaliado pelos índices Estatura para a Idade (E/I), Peso para a Idade (P/I), Peso para a Estatura (P/E), Índice de Massa Corporal para a Idade (IMC/I) em valores escore-z, com classificação referida pela Organização Mundial da Saúde. E registro alimentar com a pesagem direta dos alimentos do cardápio oferecido durante uma semana nas três instituições. Este procedimento permitiu avaliar a composição nutricional dos cardápios a partir da estimativa em valores percentuais, médios e desvios-padrão de calorias totais, macronutrientes (proteínas, carboidratos e lipídios), micronutrientes (Cálcio, Ferro, vitaminas A e C), para fazer as adequações e comparações aos valores de referências da Recommended Dietary Allowances, National Research Council e as recomendações do PNAE, segundo estágios etários, nas unidades de tempo integral, de 1-3 anos, $700 \mathrm{kcal}$; de 4-5 anos, $950 \mathrm{kcal}$ (previsão de cobertura de $70 \%$ das necessidades nutricionais diárias); e nas unidades de meio turno, nesses mesmos intervalos de idade, respectivamente, 200 e $270 \mathrm{kcal}$ (previsão de cobertura de $20 \%$ das necessidades nutricionais diárias), considerando como consumo adequado aquele com variação de até $10 \%$ acima ou abaixo de $100 \%$ dessas recomendações.

Resultados: Os pré-escolares, em maioria, com estado nutricional adequado, destacando-se aqueles da unidade de turno integral, com frequências relativas (P/I: 94,5\%; P/E: 89,5\%; IMC/I: 81,7\%). Registraram-se, ainda, porcentagens de excesso de peso maiores que os déficits, nos índices P/l (22,2\%), P/E (33,3\%), para meninas do CMEI-A; nos índices P/I, P/E, IMC/I (23,8\% cada), em meninos do CMEI-B. Quanto à adequação do perfil alimentar, somente houve convergência entre a oferta e a recomendação de $70 \%$ de cobertura das necessidades energéticas diárias, para os pré-escolares de 4-5 anos do centro de turno integral (média: 951,2+172,3kcal). Quanto aos nutrientes, houve tendência de inadequações na cobertura das necessidades diárias no cardápio ofertado em unidades de meio turno.

Conclusão: Apesar de a maioria das crianças não apresentar indicativo de risco nutricional, requer atenção a parcela que se encontrava com inadequações do estado nutricional, com ênfase aos excedentes ponderais, simultaneamente às readequações nos per capitas e nas porções do cardápio implementado nesses locais.

Palavras-chave: pré-escolar, estado nutricional, antropometria, alimentação escolar, política Nutricional. 